\title{
The Effect of HIV/AIDS upon Food Insecurity of Rural Households in Western Nigeria
}

\author{
Adewale Adetutu ${ }^{1}$, Alani Ezekiel Ayinde ${ }^{2}$, Ogundare Ayodele Oluyemisi ${ }^{3}$, Olusoji Abiodun Owoade ${ }^{1} \&$ \\ Adebowale Adebisi Jonathan ${ }^{1}$ \\ ${ }^{1}$ Department of Biochemistry, Ladoke University of Technology, Ogbomosho, Nigeria \\ ${ }^{2}$ Department of Agricultural Economics, Ladoke Akintola University of Technology, Ogbomosho, Nigeria \\ ${ }^{3}$ Department of microbiology, Federal University of Technology Akure, Ondo State, Nigeria \\ Correspondence: Adewale Adetutu, College of Health Sciences, Ladoke Akintola University of Technology, \\ P.M.B. 4000, Ogbomosho, Nigeria. E-mail: wale_836@hotmail.com / Department of Biochemistry, College of \\ Health Sciences, Ladoke Akintola University of Technology, P.M.B. 4000, Ogbomosho, Nigeria. Tel: \\ 234-816-444-1086. E-mail: wale_836@hotmail.com; aadetutu@lautech.edu.ng
}

Received: February 20, 2012 Accepted: March 23, 2012 Online Published: June 29, 2012

doi:10.5539/jas.v4n8p31 URL: http://dx.doi.org/10.5539/jas.v4n8p31

\begin{abstract}
Food insecurity and HIV/AIDS are two of the causes of mortality in Africa. Nevertheless, few studies have focused on the effect of HIV/AIDS upon food insecurity of rural households in Africa. In this study we analyzed the effect of food insecurity and welfare of farmers on the spread of HIV/AIDS. Structured questionnaires were employed for data collection from 120 farmers selected randomly from five communities. These farmers were part of continuing HIV/AIDS management of persons living with HIV/AIDS and receiving HIV antiretroviral therapy at Bowen University Teaching Hospital, Nigeria. CD4 counts were analyzed at three months intervals for each farmer after initiating HIV antiretroviral therapy. All participants had increase of CD4 count, at least 36\%, after they had been on treatment for three months; the latest increase being $36.2 \%$. Three of the participants had increases above $45 \%$ while six of them had at least $50 \%$ increases. The highest percentage increase of $171 \%$ was recorded by participants who had being on preparation for six months. This suggests that cumulative benefit continues after three months of therapy. This study provides some indications on the effect of food insecurity among rural communities in Oyo state Nigeria and suggests points of intervention.
\end{abstract}

Keywords: Africa, food insecurity, welfare, farmer, HIV/AIDS

\section{Introduction}

There are an estimated 33 million people living with HIV/AIDS worldwide and in sub-Saharan Africa the occurrence of HIV among adults is near 5\% (UNAIDS, 2002; Bryceson, \& Fonseca, 2006; Winford, 2007). HIV/AIDS and food insecurity are intertwined with poor quality of life in rural Western Africa, and an estimated $56 \%$ of the population of the rural populace lives below the poverty level (Gruber \& Caffrey, 2005). It is hard for many farmers in the rural areas to break out of poverty, as the vast majority is dependent upon the land for their source of food and nutrition. Hence, many HIV/AIDS-affected farmers are trapped in a vicious cycle of undernourishment (Gruber \& Caffrey, 2005; Winford, 2007). HIV replicates faster in populace who are malnourished, which hastens the commencement of AIDS (Swaans, 2009). Previous studies have shown the susceptibility of developing economy and subsistence agriculture to the effects of HIV/AIDS (Drimie, 2003; Tsai et al., 2011). For instance, HIV/AIDS can increase the risk of infection and the effects of the disease in turn exacerbate poverty (Bukusuba, Kikafunda, \& Whitehead, 2006; Swaans, 2009).

AIDS reduce income and agriculture productions by removing from the labour force not only the sick person, but also other members of the household who may care for the patient (Bryceson \& Fonseca, 2006; Winford, 2007). This was true for Nigeria where food prices had been increasing since early 1980s and this situation pressed the government of Nigeria to procure rice on the world market and provide it to households and distributors at subsidized prices, starting in mid-2009. Further investigation is necessary to deal with the adverse effects of HIV/AIDS on food insecurity that are found in some rural areas in Nigeria. This study therefore aims to analyze the effect of food insecurity and welfare of farmers on the spread of HIV/AIDS in western Nigeria. The specific 
objectives are to explore the effect of increasing prevalence of AIDs on rural population and examine the impacts of effects of HIV/AIDs on the farmers' agricultural production.

\section{Methodology}

\subsection{Study Area and Data Collection}

This study was carried out in Oyo State, Nigeria (Figure 1). This state located in south-western Nigeria with its capital at Ibadan. It is bordered in the North by Kwara State, by Osun State, in the south by Ogun State and in the west partly by the Republic of Benin. Oyo State is mainly occupied by the Yoruba ethnic group.

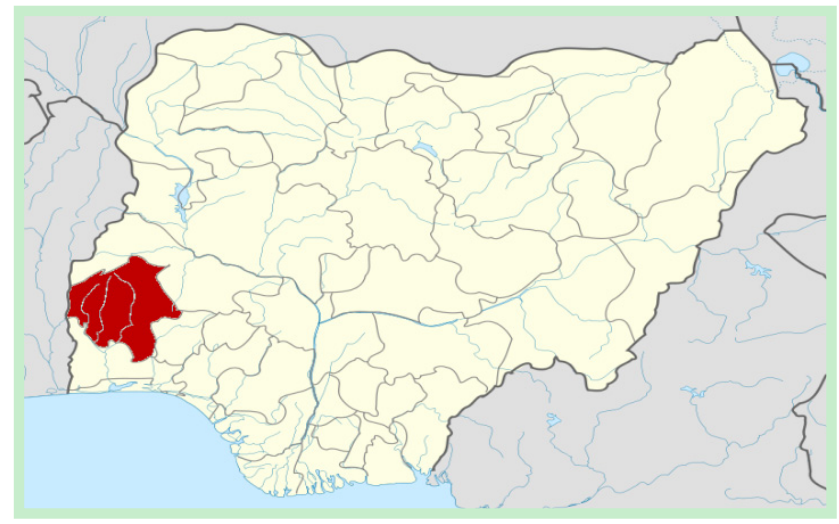

Figure 1. Location of Oyo state within western region of Nigeria

The study began after due approval was obtained from the ethics committee of the Bowen Teaching hospital, Ogbomoso, Nigeria, where the study was undertaken. Written and signed informed consents were taken from the participants after they had been diagnosed and confirmed as being HIV positive. No pregnant woman was included in the study and all participants were adults older than 30 years. Data collection was carried out between April 2006 and July 2010. These data were collected through informal semi-structured interviews with rural farmers who are receiving treatment at Bowen teaching hospital, Ogbomosho, Nigeria. All the interviews were conducted in local language (Yoruba) and translated to English. For each farmer interviewed, demographic information and agricultural activity data were collected. Local government rural agricultural extension and Bowen teaching hospital health workers were also interviewed. The interviewed workers provided data on the general food security situation of Ogbomoso, Oyo state, typical household responses to HIV/AIDS, and government and non-governmental organizational initiatives to combat the impacts of HIV/AIDS upon farmers.

\subsection{Cluster of Designation 4 (CD4) Counts}

Peripheral blood CD4 counts were carried out using a FACSCount (Becton Dickinson) flow cytometric assay according to the manufacturer's instructions. CD4 count was recorded as cell $/ \mu \mathrm{L}$.

\subsection{Data Process and Analysis}

For statistical analysis, student $t$-test was used for continuous variables and two-tailed $p$ values $<.01$ and $p<001$ were considered statistically significant. All other analyses were performed using SPSS 17.0 statistical software.

\section{Results and Discussion}

The sample consisted of 120 participants followed from August 2007 to July 2010. Forty participants were lost to follow-up. The median duration of follow-up was 1.2 years. Socio economic characteristics summary of the follow-up are provided in Table 1. The sample was predominantly female (91.4\%). Slightly more than one-half $(60.1 \%)$ of participants had experienced the death of a family member. The overall prevalence of severe food insecurity was $56.2 \%$, and nearly $67.0 \%$ of the farmers were food insecure, and $10.0 \%$ were severely food insecure, for the entire duration of follow-up (Table 1). Indicators of low socioeconomic status related with greater food insecurity are mainly low level of educational attainment, stigma and lower social support (Table 1).

Since the early days of HIV/AIDS, it has been recognized that the disease grows in several stages due to the progression of immunosuppression. The level of immunosuppression is related directly to the CD4 + T-lymphocyte count. CD4 count serves as a valuable tool to manage individuals with HIV infection in most countries of the world (Teck, Ascurra, Gomani, Manzi, Pasulani, \& Kusamale, 2005; Nicholson. Spira, Aloisio, Jones, Kennedy \& Holman, 1989). Therefore, part of the main data sourced for this study was based on CD4 counts (Table 2 and Figure 2). All participants had increase of CD4 count, at least 36\%, after they had been on 
treatment for three months; the latest increase being $36.2 \%$. Three of the participants had increases above $45 \%$ while six of them had at least $50 \%$ increases (Figure 2).

Table 1. Socio - Economic characteristics of some farmers in follow - up interviews regarding age, gender, education and personal situation

\begin{tabular}{|c|c|c|c|c|c|}
\hline & Age & Sex & $\begin{array}{l}\text { No of sessions } \\
\text { visited }\end{array}$ & Personal Situation & $\begin{array}{l}\text { Highest level of education } \\
\text { attained }\end{array}$ \\
\hline 1 & 34 & $\mathrm{~F}$ & 3 & $\begin{array}{l}\text { Takes care of sister in law }(\mathrm{HIV}+\mathrm{Ve}) \text { and } \\
\text { her children; income. }\end{array}$ & Elementary school \\
\hline 2 & 49 & $\mathrm{~F}$ & 4 & HIV + (very ill); husband died & No formal education \\
\hline 3 & 42 & $\mathrm{~F}$ & 3 & HIV + (very ill); polygamy & No formal education \\
\hline 4 & 50 & $\mathrm{~F}$ & 3 & Polygamy, (Husband died (tribal war). & Elementary school \\
\hline 5 & 45 & M & 4 & $\begin{array}{l}\text { HIV + (very ill); polygamy; (wife died } \\
\text { (tribal war). }\end{array}$ & Elementary school \\
\hline 6 & 33 & $\mathrm{~F}$ & 5 & HIV + husband died after long illness. & No formal education \\
\hline 7 & 39 & $\mathrm{~F}$ & 5 & HIV + sister and cousin died of AIDS & Elementary school \\
\hline 8 & 42 & $\mathrm{~F}$ & 5 & HIV + husband died after illness. & No formal education \\
\hline 9 & 67 & M & 5 & One son sick, daughter - in- law died & No formal education \\
\hline 10 & 47 & $\mathrm{~F}$ & 5 & Sister in - law and husband died & No formal education \\
\hline 11 & 49 & $\mathrm{~F}$ & 6 & Husband died. & Secondary school \\
\hline 12 & 26 & M & 7 & $\begin{array}{l}\text { Parents died (Due to AIDS); looks after } \\
\text { brothers and sisters. }\end{array}$ & Elementary school \\
\hline 13 & 47 & $\mathrm{~F}$ & 7 & $\begin{array}{l}\text { Brother died (Stroke); left with four } \\
\text { Orphans. }\end{array}$ & No formal education \\
\hline 14 & 66 & $\mathrm{~F}$ & 7 & $\begin{array}{l}\text { One daughter died; takes care of two } \\
\text { orphans. }\end{array}$ & Elementary school \\
\hline
\end{tabular}

Table 2. CD4 counts of some of the participants

\begin{tabular}{|c|c|c|c|c|c|c|}
\hline & Card number & Basal CD4 count (cell/uL) & Date & $\begin{array}{c}\text { Current CD4 } \\
\text { Count (cell/uL) }\end{array}$ & Date & $\begin{array}{l}\text { Remarks } \\
\text { (months) }\end{array}$ \\
\hline 1 & UC-07-1007 & 410 & January 25, 2007 & 605 & April 26, 2007 & 3 \\
\hline 2 & UC-06-2679 & 283 & December 15,2006 & 515 & March 8, 2007 & 3 \\
\hline 3 & UC-05-2127 & 199 & December 7, 2006 & 540 & June 7, 2007 & 6 \\
\hline 4 & UC-05-0358 & 412 & November 30, 2006 & 1045 & May 31, 2007 & 6 \\
\hline 5 & UC-07-1007 & 410 & January 18, 2007 & 605 & April 19, 2007 & 3 \\
\hline 6 & UC-07-1270 & 216 & January 18, 2008 & 340 & April 19, 2008 & 3 \\
\hline 7 & UC-06-1270 & 397 & December, 14, 2009 & 540 & June 14,2010 & 6 \\
\hline 8 & UC-06-2241 & 286 & October 122009 & 420 & April 12, 2010 & 6 \\
\hline 9 & UC-06-2163 & 210 & November 2006 & 401 & February, 2007 & 3 \\
\hline 10 & UC-06-2169 & 309 & November 23, 2006 & 550 & May 24, 2007 & 6 \\
\hline
\end{tabular}




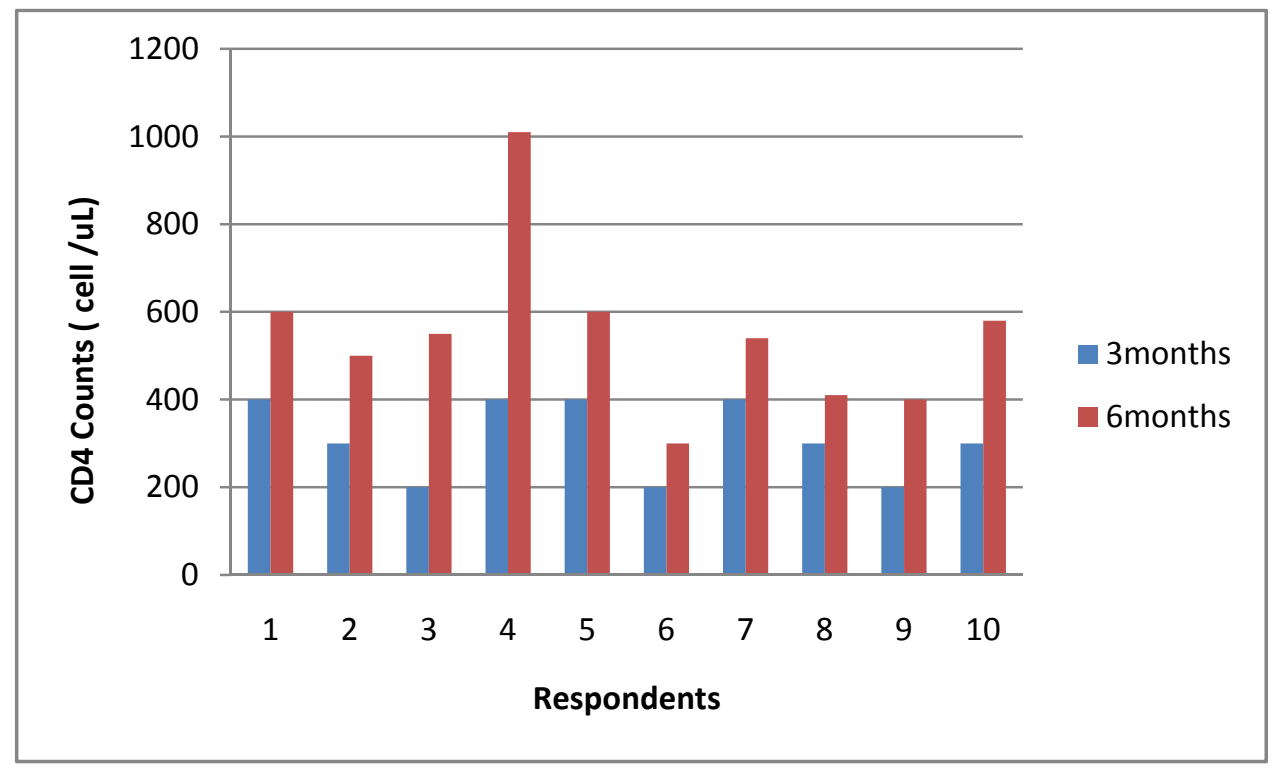

Figure 2. Comparing the CD4 counts of respondents at 3 months (blue bars) and 6 months (brown bars)

Results from the fixed effects estimation are presented in Table 3. In this estimation, social support and HIV/AIDS stigma retained statistically significant associations with food insecurity. In addition, increases in stigma intensity were associated with increases with changes in food insecurity, indicating that changes in HIV stigma and social support did influence farmers on changes in food insecurity. It was similarly observed that the welfare of farmers and level of food security were adequately affected by the spread of HIV/AIDS in the study area and that there was a significant effect on the level of spread. This observation is in accordance with previous publications on impacts of HIV/AIDS on rural populations (Holben, 2010; Gill, 2010). This study established that food insecurity is frequent among the selected farmers living with HIV/AIDS in rural Nigeria. We also observed that greater levels of HIV-related stigma and lower levels of educational attainment are strong predictor of food insecurity among the participants (Tables 1 and 3).

Table 3. Fixed effects estimates of the relationship between change in food insecurity and changes in farmers welfare $(\mathrm{n}=10)$

\begin{tabular}{llll}
\hline Variable name & \multicolumn{1}{l}{$\boldsymbol{c}$} & $\mathbf{( 9 9 \%}$ CI) \\
Season of visit & & \\
Raining season & Ref & \\
First planting season (April or August) & 0.57 & $(0.26,2.10) *$ \\
Second planting season (October or November) & 1.31 & $(1.72,3.43) * *$ \\
Duration of antiretroviral treatment (per month) & -0.02 & $(-0.13,0.014)$ \\
Social Support count & -0.66 & $(-2.45,-0.32) *$ \\
HIV/AIDS-Stigma count & 1.10 & $(0.71,1.32)^{*}$ \\
\hline
\end{tabular}

$*$, and $* *$ denote statistical significance at the $p<0.01$, and $p<0.001$ levels, respectively

The findings of this study have significant policy implications for the care of farmers and people living with HIV/AIDS in rural areas. Although, a handful of studies have recognized the effects of food insecurity in rural areas of the world, less research has focused on food insecurity among farmers and people living with HIV/AIDS (Tsai et al., 2011).

Our study provides a local evaluation of effects of food insecurity among farmers living with HIV/AIDS. It can be concluded that poverty, gender inequality, stigma and food insecurity undermine farmers' performance. Therefore, aggressive interventions are desirable to deal with food insecurity and/or HIV-related in the perspective of ongoing 
HIV treatment by the farmers. These strategies may provide evidence, with further randomized study, to be promising interventions that can break off the cycle of food insecurity and HIV/AIDS.

\section{Acknowledgements}

The valuable contributions of Prof T. K Oloke on CD4 were gratefully acknowledged. The authors are most grateful to Bowen University Teaching Hospital managements for the use of their patients and facilities for this work.

\section{Conflict of interest}

The authors declare no conflict of interest concerning the work reported in this paper.

\section{References}

Bryceson, D. F., \& Fonseca, J. (2006). Risking death for survival: Peasant responses to hunger and HIV/AIDS in Malawi. World Development, 34(9), 1654-1666. http://dx.doi.org/10.1016/j.worlddev.2006.01.007

Bukusuba, J., Kikafunda, J. K., \& Whitehead, R. G. (2007). Food security status in households of people living with HIV/AIDS (PLWHA) in a Ugandan urban setting. British Journal of Nutrition, 98, 211-217. http://dx.doi.org/10.1017/S0007114507691806

Drimie, S. (2003). HIV/AIDs and land: Case studies from Kenya, Lesotho and South Africa. Development Southern Africa, 20(5), 647-658. http://dx.doi.org/10.1080/0376835032000149289

Gill, T. B. (2010). Modeling the impact of HIV/AIDS upon food security of diverse rural households in Western Kenya. Agricultural Systems, 103(5), 265-281. http://dx.doi.org/10.1016/j.agsy.2010.01.007

Gruber, J., \& Caffrey, M. (2005). HIV/AIDS and community conflict in Nigeria: implications and challenges. Social Science \& Medicine, 60, 1209-1218. http://dx.doi.org/10.1016/j.socscimed.2004.06.053

Holben, D. (2010). Position of the American Dietetic Association: Food insecurity in the United States. Journal of the American Dietetic Association, 110(9), 1368-1377. http://dx.doi.org/10.1016/j.jada.2010.07.015

Nicholson, J. K., Spira, C. H., Aloisio, Jones, B. M., Kennedy, M. S., \& Holman, R. C. (1989). Serial determinations of HIV-1 titers in HIV- infected homosexual men: association of rising titers with CD4 Tcell depletion and progression to AIDS, AIDS Res Hum Retroviruses, 5, 205-215. http://dx.doi.org/10.1089/aid.1989.5.205

Swaans, K. Broerse, J., Meincke, M., Mudhara, M., \& Bunders, J. (2009). Promoting food security and well-being among poor and HIV/AIDSS affected households: Lessons from an interactive and integrated approach. Evaluation and Program Planning, 32(1), 31-42. http://dx.doi.org/10.1016/j.evalprogplan.2008.09.002

Teck, R., Ascurra, O., Gomani, M., Manzi, P., Pasulani, O., \& Kusamale, J. (2005). WHO clinical staging of HIV infection and disease, tuberculosis and eligibility for antiretroviral treatment: relationship to CD4 lymphocyte counts. Int J Tuberc Lung Dis, 9, 258-262.

Tsai, C. A., Bangsberg, D. A., Emenyonu, N., Senkungu, K. J., Martin, N. J., \& Weiser, D. S. (2011). The social context of food insecurity among persons living with HIV/AIDS in rural Uganda. Social Science \& Medicine, 73(12), 1717-1724. http://dx.doi.org/10.1016/j.socscimed.2011.09.026

UNAIDS. (2002). Report on the global HIV/AIDS epidemic. Geneva: Joint United Nations' Programme on HIV/AIDS.

Winford, M. (2007). The povert-HIV/AIDS nexus in Africa: A livelihood approach. Social Science \& Medicine, 64(5), 1032-1041. http://dx.doi.org/10.1016/j.socscimed.2006.10.009 